\title{
ENVIRONMENTÁLNÍ ASPEKTY VÝUKY GEOGRAFIE NA 2. STUPNI ZÁKLADNÍCH ŠKOL
}

\author{
Michal Staněk, Jiří Rypl, Pavla Zrzavecká
}

\begin{abstract}
This contribution reviews the results of the educational module Geography within the framework of the OP VVV project: „Enhancing the Quality of Education, Developing Key Competences, Areas of Education and Literacy". Regular cooperation between schools and the mutual enrichment of the relevant actors (school teachers, academics, and university students) is provided within the so-called "Community of Practice". Collaboration is provided in the challenge themes with the application of innovative, activation and reflective approaches. The didactic case report studies selected thematic lessons that can positively influence the future behaviour of pupils. The didactic case report: „The Plastic Sea" deals with the global problem of plastic waste in the oceans and the associated increasing consumption of plastics in the world. The didactic case report "It's time to get into the wardrobe" deals with the issues of textile and clothing production which is linked with many environmental and health aspects.
\end{abstract}

Keywords: environment, geography, teaching, didactics, cooperation, igelitart

\section{Úvod}

Katedra geografie Pedagogické fakulty Jihočeské univerzity v Českých Budějovicích prrijala spoluúčast na realizaci projektu OP VVV „Zvýšení kvality vzdělávání žáků, rozvoje klíčových kompetencí, oblastí vzdělávání a gramotností“, jehož garantem je Pedagogická fakulta Univerzity Karlovy ve spolupráci s dalšími vysokými školami, resp. Masarykovou univerzitou v Brně a Technickou univerzitou v Liberci.

Samotná spolupráce probíhá v několika úrovních. Pracovníci zmíněných vysokých škol (oboroví didaktici, speciální pedagogové a psychologové se zaměřením na psychodidaktiku) participují na odborných aktivitách projektu a dále spolupracují s učiteli základních a středních škol - tím je zajištěno propojení teoretické př́ípravy vzdělávání učitelů a učitelské praxe (Korthagen et al., 2011). Podpora profesních kompetencí učitelů a studentů má ve výsledku kličcoý dopad na žáky v souladu s definovanými cíli RVP (Rámcový vzdělávací program pro základní vzdělávání, 2017).

$\mathrm{V}$ rámci projektu byla formována tzv. Společenství praxe pro vzájemné sdílení zkušeností aktérů, možnost inspirovat se a vytvářet didaktické i jiné odborné materiály (participující učitelé a školy poté získají př́stup do databanky 
výukových materiálů, metodik, vzdělávacích programů, učebnic, pracovních listů, videosekvencí atd.). Uplatnění inovativních, aktivizačních a reflektivních přístupů rozvíjí oblasti, které jsou projektem podpořeny. Výzva řeší témata matematická gramotnost, čtenářská gramotnost, informační gramotnost, občanské a sociální kompetence a vzdělávací oblast Člověk a př́roda, kam jsou zahrnuty vzdělávací moduly chemie, fyzika, prrírodopis a zeměpis.

Př́ípravná fáze projektu vygenerovala dílčí témata $\mathrm{v}$ jednotlivých vzdělávacích modulech (tab. 1) jako motivační prostř̌edek k primárnímu řešení a diskuzi účastníků.

\section{Tab. 1: Návrhy řešených témat vzdělávacího modulu Zeměpis}

Table 1: Suggestions for the topics of the Geography module

\section{Určujeme zeměpisnou polohu a čas}

Určování absolutní a relativní zeměpisné polohy, popis/vysvětlení cesty z bodu A do bodu B. Určení polohy nejen podle př́strojů a mapy, ale také umět se zeptat na cestu a druhému ji poradit/vysvětlit. Podle získaných informací se následně dokázat $\mathrm{v}$ daném prostoru orientovat. $\mathrm{V}$ kterou dobu je možné u nás ve střední Evropě sledovat př́mé přenosy sportovních akcí ze vzdálených lokalit světa (např. Severní a Jižní Ameriky, Asie či Austrálie).

\section{Kontinentální drift a litosférické (tektonické) desky}

Kontinentální drift a tektonické desky vytváŕí „tektonickou“ mapu světa, ze které lze vyčíst/vysvětlit oblasti $\mathrm{s}$ horotvornou (vrásová, sopečná a kerná pohoří) a sopečnou činností, rizikové zóny zemětřesení a vln tsunami. Znalosti a dovednosti, jak se chovat v oblastech prírodních rizik (sopečná erupce, zemětřesní, tsunami). Všechny tyto procesy mají původ ve vnitřních geomorfologických silách Země.

\section{Vnějš́ geomorfologické procesy ovlivňující charakter krajiny}

Založeno na erozním cyklu, při němž se stř́dá eroze (vnější geomorfologické procesy) se zdvihem povrchu (vnitřní geomorfologické procesy). Objasnit rozdíl mezi rovinou a nízinou. Proti vnitřním geomorfologickým silám působí vnější geomorfologické síly (větrná, vodní, mrazová eroze atd.) a vytvárí charakteristické rysy reliéfu (krajiny). Interpretace příčného a podélného profilu reliéfem, př́ípadně vodním tokem.

\section{Př́strojová měření ve fyzické geografii}

Př́strojová měření ve fyzické geografii implementují prvky badatelsky orientovaného vyučování do hodin zeměpisu. Touto formou je možné ověřovat různé úlohy (měření rychlosti větru, měření průtoku vodního toku, zjištování půdního typu atd.) z dílčích disciplín fyzické geografie (meteorologie a klimatologie, hydrologie, pedogeografie atd.) př̀i práci $\mathrm{v}$ terénu. Možné jsou dílčí experimenty $\mathrm{k}$ ověřování vzniku různých fyzickogeografických jevů.

\section{Dopady lidské činnosti na životní prostředí}

V př́rodě fungují vztahy akce a reakce (determinismus). Činnost člověka vyvolává změny $\mathrm{v}$ prostředí, které jsou vědecky předpověditelné (např. znečištování ovzduší, vody, eroze půd). Odezva prírodních procesů na činnost člověka - smog, splavování/smývání půdy atd. Změna chování člověka - snižování zdrojů znečištění, změna technologie při obdělávání půd či využívání plodin na orné půdě, které zabraňují odnosu půdy aj. 


\section{Teoreticko-metodická východiska}

Jedná se o prưřrezová témata $\mathrm{s}$ využitím transdidaktického přistupu, který pojímá výuku geografie transdisciplinárně bez oborové izolace. (Slavík a kol., 2017) Vzniká tím badatelské zázemí pro mezipředmětové vztahy a společný mezioborový diskurz. $\mathrm{V}$ tomto príspěvku se zaměříme na environmentální tématiku dopadů lidské činnosti na životní prostředí, viz tab. 2; právě takové téma otevře potenciál geografie (často zaměřené interdisciplinárně) k multidisciplinární kooperaci.

Společně vytvořené a sdílené výstupy z projektu (různé výukové materiály, pracovní sešity, videa, didaktické metody a kazuistiky) byly ověřovány v praxi zapojených učitelů ze základních a středních škol, kteří využívali nejen individuálních konzultací s pracovníky pedagogických fakult, ale také se svými kolegy z jiných škol.

Tab. 2: Očekávané výstupy vzdělávacího obsahu Životní prostředí podle RVP ZV Table 2: Expected outcomes of educational content Environment by RVP ZV

Z-9-5-01 žák porovnává různé krajiny jako součást pevninské části krajinné sféry, rozlišuje na konkrétních př́kladech specifické znaky a funkce krajin

Z-9-5-02 žák uvádí konkrétní př́klady př́rodních a kulturních krajinných složek a prvků, prostorové rozmístění hlavních ekosystémů (biomů)

Z-9-5-03 žák uvádí na vybraných př́kladech závažné důsledky a rizika prrírodních a společenských vlivů na životní prostředí

\section{Didaktická kazuistika: Plastové moře}

V první řadě je nutné seznámit se $\mathrm{s}$ ukotvením učiva $\mathrm{v}$ rámci vzdělávacích oblastí, následně průřezových témat a cílů výuky.

Téma zasahuje do následujících vzdělávacích oblastí RVP ZV: Člověk a př́roda (zeměpis, př́rodopis, chemie); Člověk a společnost (výchova k občanství); Člověk a zdraví (výchova ke zdraví); Umění a kultura (výtvarná výchova).

Téma se v menší či větší míře dotýká všech prưřezových témat RVP ZV: Osobnostní a sociální výchova (utváření praktických životních dovedností); Výchova demokratického občana (rozvoj kritického myšlení, konstruktivní řešení problémů $\mathrm{s}$ respektem $\mathrm{k}$ druhým); Výchova $\mathrm{k}$ myšlení v evropských a globálních souvislostech (smysl pro zodpovědnost); Multikulturní výchova (smysl pro spravedlnost, solidaritu a toleranci); Environmentální výchova (pochopení komplexnosti a složitosti vztahů člověka a životního prostředí, poznání významu odpovědnosti za jednání společnosti i každého jedince ve vztahu k prostředí); Mediální výchova (schopnost analyzovat nabízená mediální sdělení, posoudit jejich věrohodnost a vyhodnotit jejich komunikační záměr). 
Cíle tematického modulu: žák navrhuje možná řešení problému plastového odpadu v oceánech a mořích; žák zaujímá vlastní postoje $\mathrm{k}$ tomu, co sám může dělat s problematikou plastového odpadu; žák posuzuje efektivitu navrhnutých řešení pro odstranění problému plastového odpadu; žák společně s ostatními spolužáky vytváří plastickou koláž jako symbol globálního problému plastového odpadu; žák reflektuje svůj prínos pro vytvoření společného díla.

Tento tematický modul obsahuje významný potenciál multikulturního a globálního rozvojového vzdělávání. Zároveň klade nároky na dostatečnou přípravu a informovanost vyučujícího, jelikož se jedná o aktuálně velmi diskutované téma v národním i mezinárodním měřítku. Pro žáky nabízí možnost uplatnění jejich tvořivosti během výtvarných aktivit - IgelitART propojuje současné světové umění a design s aktuálními globálními tématy. Časová disponibilita všech zmíněných aktivit zahrnuje 1 vyučovací hodinu o klasické délce 45 minut.

Vstupní aktivitu představuje ,igelitový kvíz“, který je sondou do mezipředmětových vztahů a uvědoměním vlastních zkušeností žáků (výroba plastů, spotřeba igelitových tašek a sáčků $\mathrm{v}$ domácnosti, životnost igelitového sáčku, recyklace a opakované používání plastů, zákaz igelitek zdarma). Následuje společná kontrola správných odpovědí a její motivační zhodnocení.

Expoziční část výukového modulu vychází ze shromáždění dostupného plastového materiálu z prostor trrídy, popř. celé školní budovy (PET lahve, igelitové tašky, mikrotenové sáčky aj.). Názorné umístění do vytyčeného 1 metru čtverečního na podlaze vede ke komparaci se statisticky doloženými údaji o plastovém odpadu ve světových oceánech a mořích (jaké množství plastových odpadů plave v průměru na 1 metru čtverečním oceánské hladiny). V komparaci lze pokračovat návodnými otázkami o objemu plastového odpadu za celou tř́du / školu / město / stát / planetu. Dále je možné tyto údaje porovnat za časový horizont dne / týdne / roku. Domácí projekt vhodně doplňuje tento odhad o skutečně ověřené údaje, např. žáci mohou počítat a zaznamenávat do tabulky týdenní spotřebu plastu jejich či celé rodiny.

Atmosféru dokreslí fotografie plastového odpadu a jejich rozbor formou společné diskuze - brainstorming (první dojmy a postřehy, doplňující otázky je dobré zaznamenávat na flipchart a využít $\mathrm{v}$ závěrečné reflexi).

Pro vizualizaci celé problematiky poslouží velký průsvitný igelit k naznačení hladiny moře (ideálně igelit používaný na překrytí nábytku před malováním). Rozložený igelit symbolizuje moře, které žáci jeho uchopením uvedou do pohybu (viz obr. 1). Perspektiva žáků se přiblíží situaci dotčených oblastí prrímo v učebně. Hodiny výtvarné výchovy a př́rodopisu mohou vhodně doplnit př́slušnou část modulu o prredstavy fiktivních tvorů žijících v takovém moři plastu, přičemž žáci zapojí svou fantazii a kreativitu. Výukovou nadstavbou jsou prvky osobnostní a sociální výchovy spojené s životem $\mathrm{v}$ takovém moři, zosobněním jeho pocitů a nálad. 
Obr. 1: Moře plastového odpadu v režii žáků při vyučovací hodině

Figure 1: A sea of plastic waste directed by pupils at a class

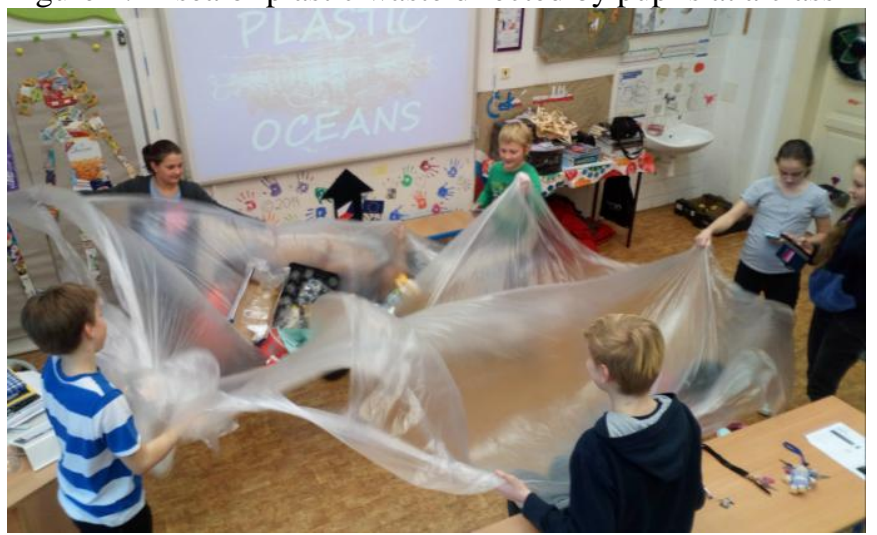

Zdroj: Staněk (2018)

Odkaz na příslušnou fotogalerii školy: http://www.zs-bhrabala.cz/fotogalerie/skola/ 2018-06-10-zemepisny-krouzek-projekt-op-vvv

Dopady znečištění vod na živočichy $\mathrm{v}$ nich žijící vedou k angažovanější argumentaci při diskuzním fóru žáků a učitele, jenž si udržuje nezúčastněnou pozici a otázkami pouze reguluje samotnou diskuzi. Co tedy lze dělat s plastovým odpadem dříve, než se dostane do moří a oceánů? Promyšlené nápady sepíší žáci ve skupinách na kartičky a ty lze poté třídit podle toho, jak účinně řeší problém plastového odpadu. V závěru hodiny mohou skupiny představit své varianty a žáci sepsat (metodou volného psaní), co my sami s tím můžeme dělat?

Reflexe takového modulu přináší otevřený dialog mezi žáky a učitelem, interakci mezi žáky navzájem, možnost nahližet na svět kolem nás z jiného úhlu pohledu, obohatit své znalosti i postoje a ve výsledku lépe poznat sebe sama. Povědomí žáků o celosvětovém problému odpadů se rozširíí, což může pozitivně ovlivnit jejich budoucí jednání.

\section{Didaktická kazuistika: Je na čase zapátrat v šatníku}

Projektové vyučování pro žáky 9. ročníku zohledňuje dopady lidské činnosti na životní prostředí a vychází z učiva přírodopisu (devastace krajiny, ohrožení rostlin a živočichů); zeměpisu (oděvní průmysl, pěstování bavlníku, místo spotřeby); chemie (používání pesticidů); občanské výchovy (pracovní podmínky, minimální mzda). Zapojeny jsou průřezová témata, klíčové kompetence (včetně pracovních činností) i mezipředmětové vztahy (vyjma zmíněných předmětů také finanční gramotnost). Časový harmonogram zahrnuje 3 vyučovací hodiny, ideálně sloučené do blokové výuky. 
Úvodem žáci zhlédnou dokumentární film „Co se nenosi““, který poslouží jako motivace ke skupinové diskuzi. Nadstavbové informace získají rozborem textu o problematice výroby a negativních vlivech prostředí na obyvatele.

Skupinová práce se zaměřuje na životní cyklus oděvů. Každá ze skupin dostane jiný výrobek - např. tričko, džíny, trekové boty, flísovou mikinu. Úkol všech skupin je stejný: zamyslet se nad historií, získáváním surovin, výrobou produktu, distribucí, prodejem, délkou životnosti a recyklací daného výrobku. Následuje společné shrnutí konkrétních činností u jednotlivých fází životního cyklu oděvu či obuvi.

V další fázi žáci vyplní pracovní list za pomoci školního atlasu, pracovat s mapou mohou i při použití interaktivní tabule. Dotčenou oblast jihovýchodní Asie zaznamenají do slepé mapy světa, vyznačí a pojmenují státy regionu, ve kterých se pěstuje bavlník, šipkou graficky znázorní místa spotřeby. Žáci se také seznámí s případovou studií, debatují nad vybranými možnostmi nákupu oblečení a pomocí vlastních argumentů zvolí vyhovující nákupní strategii.

Praktickým úkolem je závod na dlouhé niti, při kterém si žáci rukodělnou činností vyzkoušejí pracovní nasazení dělnic (viz obr. 2). Učitel poskytne každému žákovi jehlu, nit, kousek látky a cca 10 knoflíků. Úkolem je navléknout nit na jehlu a pevně prrišít co největší množství knoflíků za zvolený časový úsek 5-ti minut. Žáci si na závěr uvědomují, jak náročná je tato dílčí činnost při výrobě nového kusu oblečení v konfrontaci s aktuálními módními trendy.

Závěrečnou diskuzí na téma „Jak a kde se vyrábí Vaše tričko?“ jsou splněny všechny kroky, které vytváŕí projektové vyučování - od představení projektu a popis jeho průběhu, rozdělení žáků do studijních skupin, přes samotnou realizaci projektu (pracovní list), praktické výstupy, až po finální reflexi.

Obr. 2: Žáci během praktické aktivity přišívají knoflíky

Figure 2: Pupils sew buttons in practice

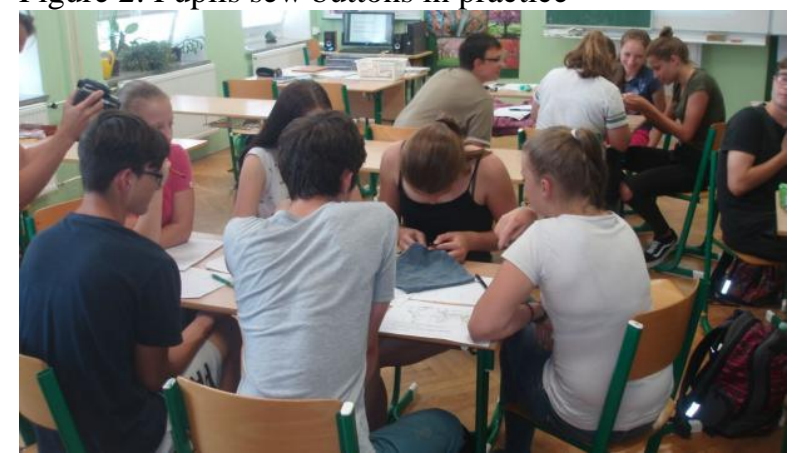

Zdroj: Rypl (2018)

Odkaz na příslušnou fotogalerii školy: http://www.zsnetvorice.cz/index.php?page= projekt-op-vvv-sc2-5 


\section{Závěr}

Environmentální aspekty výuky zeměpisu široce zasahují do mezipředmětových vazeb a prostřednictvím nich mapují vztah př́rody a společnosti, využívají tedy průniku přírodních a společenských (lépe sociohumanitních) věd. Konkrétním obsahem tohoto tematického celku je trvale udržitelný život a rozvoj, principy a zásady ochrany přírody a životního prostředí, chráněná území přírody, globální ekologické a environmentální problémy lidstva (RVP ZV). Žáci mají možnost uvědomit si dynamicky vyvíjející se vztahy mezi člověkem a jeho prostředím na základě ekologických, ekonomických, vědeckotechnických, politických a občanských témat s možností různých variant řešení environmentálních problémů. Aktuální témata kladou důraz na dostatečnou informovanost vyučujících, kteří mají pro svou fundovanou přípravu $\mathrm{k}$ dispozici velké množství podpůrných prostředků (odborných publikací, mezinárodních statistik, dokumentárních filmů apod.).

Výukové moduly orientované na environmentální vzdělávání jsou zapojenými učiteli projektu vnímány (v porovnání s ostatními učebními celky zeměpisu) jako okrajové téma, na které se $\mathrm{v}$ hodinách nedostává časové dotace. $\mathrm{Z}$ analýzy vzdělávacích programů zapojených škol vyplývá, že problematika dopadů lidské činnosti na životní prostředí přesahuje do výuky zeměpisu zejména z hodin prrírodopisu, ekologie či společenských věd. Jako vhodné a žádoucí se jeví doplňovat tímto způsobem učivo jednotlivých prŕrodních sfér (atmosféra a její znečištění, kácení vzácného dřeva $\mathrm{v}$ tropických pralesích aj.), či zařadit výuku př́mo $\mathrm{k}$ dotčené lokalitě při výuce regionální geografie (např. nedostatek vody ve státech Perského zálivu, rozšiřování pouští v oblasti subsaharské Afriky). Nabízí se široká paleta forem výuky od zážitkové, badatelské, integrované, přes týmové vyučování a ř́zené diskuzní fórum až $\mathrm{k}$ filozofii pro děti. To vše žákům pomáhá reflektovat jejich životní styl a hodnotovou orientaci, jednat v souladu s principy udržitelnosti rozvoje, aktivně se účastnit na ochraně a utváření životního prostředí.

Přínosem pro zapojené učitele výzvy je navázání kontaktů s kolegy dalších škol a jiných regionů, konzultace s akademickými pracovníky z pedagogických fakult, pravidelná setkání na vertikální (bez rozlišení vzdělávacího modulu) i horizontální úrovni. Každé zvolené téma bylo postupně řešeno v kontextu tř́i etap zaměřeno na kurikulum, na výuku a na aktéry. Během realizace projektu učitelé rozvíjí své profesní kompetence zejména $\mathrm{v}$ oblasti didaktické, metodické a diagnostické. Výsledným benefitem se pro ně stala databanka vytvořených a ověřených materiálů (metodik, pracovních listů, pomůcek, námětů a inspirací atd.) na podkladě profesních portfolií. Obdobně jako je žákovské portfolio dokladem o jeho učebních výsledcích, učitelské portfolio vypovídá o průběhu i dosažených výsledcích projektu. Dále umožňuje sebrané materiály třídit, reflektovat, hodnotit, prezentovat, sdílet, př́ípadně využít pro další plán profesního rozvoje (Trunda, 2012). 


\section{Poděkování}

Př́spěvek byl zpracovaný v rámci projektu OP VVV „Zvýšení kvality vzdělávání žáků, rozvoje klíčových kompetencí, oblastí vzděláváni a gramotnosti", reg. č. CZ.02.3.68/0.0/0.0/16_011/0000664 a za prispěni grantu Jihočeské univerzity $v$ Českých Budějovicích č. 160/2016/S: „Kličové kompetence v kontextu mezioborových vazeb př́rodovědných predmětü “.

\section{Literatura}

JANÍK, T. a kol. 2013. Kvalita (ve) vzdělávání: obsahově zaměrený přistup ke zkoumání a zlepšováni výuky. Brno: Masarykova univerzita, 2013. $434 \mathrm{~s}$. ISBN 978-80-210-6349-5.

KORTHAGEN, F. A. J. - JANÍK, T. - NAJVAR, P. 2011. Jak spojit praxi s teorií: didaktika realistického vzdélávání učiteli̊. Brno: Paido, 2011. $294 \mathrm{~s}$. ISBN 978-80-7315-221-5.

Rámcový vzdělávací program pro základni vzdělávání [online]. 2017. [cit. 201809-10]. Praha: VÚP. Dostupné na internetu: http://www.msmt.cz/file/43792/

SLAVÍK, J. - JANÍK, T. - NAJVAR, P. - KNECHT, P. 2017. Transdisciplinární didaktika: O učitelském sdíleni znalostí a zvyšování kvality výuky napřič obory. Brno: Masarykova univerzita, 2017. 455 s. ISBN 978-80-210-8568-8.

TRUNDA, J. 2012. Profesní portfolio učitele: soubor metod $k$ hodnocení a sebehodnocení. Praha: Národní ústav pro vzdělávání, školské poradenské zařízení a zařízení pro další vzdělávání pedagogických pracovníků, 2012. 19 s. ISBN 978-80-87063-62-0.

\section{ENVIRONMENTAL ASPECTS IN TEACHING GEOGRAPHY AT SECOND LEVEL OF PRIMARY SCHOOLS}

\section{Summary}

In the scope of the project OP VVV „Enhancing the Quality of Education, Developing Key Competences, Areas of Education and Literacy“ the Community of Practice has been founded in order to share experiences, get an inspiration and create didactic and other expert materials. The schools and teachers taking part in this project will later be granted access to a data bank of educational materials. The area Human and Nature includes educational module Geography, in which apart from other topics (determining of the geographical location and time, continental drift, tectonic plates etc.) the impact of human activity to the environment is being addressed. The conclusions of the project have been tested in practice by the teachers of elementary and high schools involved in this project, who were consulting their colleagues from pedagogical faculties as well as other experts. 
In the topical module „A Sea of Plastic“ the students suggest possible solutions to the problem of plastic waste in the oceans and seas; thy take their own approaches to the problem and to the activities they can do to help; they consider the effectivity of the suggested solutions to eliminate the plastic waste; together with other students create a plastic collage as a symbol of the global issue of the plastic waste; they reflect their contribution to the creation. This module offers a great potential of multicultural and global education and gives the students an opportunity to apply their creativity during the art activity. Discussion about the impacts of the polluted waters opens an open dialogue between the students and the teacher or among students and the opportunity to view the world around us from a different point, to enrich the students' knowledge and attitudes and in conclusion to give the students the opportunity to get to know themselves better.

The project module "It's Time to Open the Wardrobe“ for students of the 9th grade addresses impacts of human activities on the environment and is derived from classes of biology (devastation of landscape, planting of cotton, place of consumption); chemistry (usage of pesticides); civics (work conditions, minimum wage). It also includes cross-cutting themes, key competences (including handcrafts) and interdisciplinary relationships (also financial literacy). All the steps creating project teaching (from the description of the activity to its realization and conclusions) are fulfilled, including the final discussion „Where was my T-shirt made?"

The environmental aspects of Geography intervene with the interdisciplinary relationships and through them it views the relationship of the nature and society, it uses the intersection of natural and social sciences. The concrete content of this topical unit is the sustainable development and life, principles of the protection of environment and nature, protected areas, global environmental and ecological issues of humanity. The students have an opportunity to realize the evolving relationships between humans and their environment. Contemporary topics emphasize sufficient knowledge of teachers, who should also be provided with sufficient materials. The problematics of the human impacts intersects especially with biology, ecology or social sciences. There are many possible forms of teaching, from experiential, integrated, team teaching or discussion to Philosophy for Children or research. All of the above helps the students think about their lifestyle and values, act according to the principles of sustainable development, actively participate in protecting and creating our environment.

\section{Mgr. Michal Staněk \\ Mgr. Jiř́i Rypl, Ph.D. \\ Mgr. Pavla Zrzavecká}

Katedra geografie PF JU v Českých Budějovicích

Jeronýmova 10, 37115 České Budějovice

E-mail: mstanek@pf.jcu.cz,rypl@pf.jcu.cz,ZrzaveckaP@seznam.cz 